Patient controlled analgesia システムを用いた

皮下持続注入法による術後疼痛管理

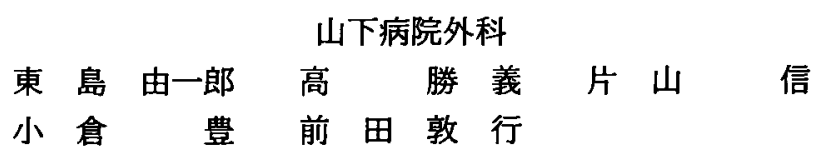

われわれは腹部外科手術症例135例を対象とし，1）ププレノルフィン皮下持続注入群 90例，2） PCA (Patient Controlled Analgesia) システムを用いたププレノルフィン皮 下持続注入群20例，3）PCA システムを用いたペンタソシン皮下持続注入群20例の 3 群 について術後疼痛管理の有用性を比較検討した。

その結果, 術後疼痛管理においてププレノルフィン皮下持続注入法は有奻であり, PCA システムを用いることにより更に医療業務の安全な省力化を図る上で有用である と思われた.

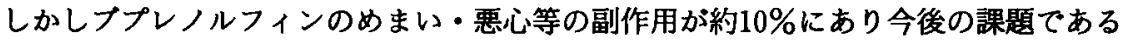
と思われた。ペンタゾンン皮下持続注入はブプレノルフィンに比較して鎮痛効果が有意 に劣り,かつ安全性に問題があった.

索引用語：術後疼痛管理, 皮下持続注入法, PCA システム, ププレノルフィン

\section{はじめに}

当院における術後疼痛管理として1994年 8 月まて は，疼痛時に主にペンタソシンの筋注を行っていた. しかし術後患者の苦痛を持続的に楥和する必要性か ら，硬膜外注入法に代わる簡易で安全な方法としてブ プレノルフィンの皮下持続注入法を1994年 9 月から開 始した。

また1995年 4 月から保険適応となった患者自身が疼 痛時にボタンを押して投与でる patient controlled analgesia (PCA) システムを導入した. ブプレノル フィンの副作用であるめまいや悪心等を少なからず経 験したため一時期ペンタソシンン変更したが, 安全性 に問題が生じたため11月からは再びブプレノルフィン を使用し現在に至っている。これらの有用性を比較検 討した。

\section{対象および方法}

腹部外科手術症例を対象として,ブプレノルフィン 皮下持続注入群 (Bu 群) 95例, PCA システムを用い たププレノルフィン皮下持続注入群（PCA-Bu 群）20 例, PCA システムを用いたペンタソシン皮下持続注入

1996年 4 月30日受付 1996 年 9 月 4 日採用
表 1 対累患者の背景因子

\begin{tabular}{|c|c|c|c|}
\hline & Bu 群 & PCA-Bu 群 & PCA-Pe 群 \\
\hline 人数 & 95 & 20 & 20 \\
\hline 男：女 & $57: 38$ & $15: 5$ & $12: 8$ \\
\hline 年制 (藏) & $62.5 \pm 10.3$ & $59.6 \pm 10.1$ & $57.1 \pm 15.7$ \\
\hline 体重 (kg) & $54.7 \pm 10.2$ & $54.7 \pm 8.5$ & $56.2 \pm 10.0$ \\
\hline \multicolumn{4}{|l|}{ 術式 } \\
\hline 胃切除, 全摘術 & 36 & 5 & 9 \\
\hline 結腸切除術 & 27 & 3 & 2 \\
\hline 直腸切断術 & 2 & 0 & 1 \\
\hline 胆荎摘出術 & 15 & 3 & 4 \\
\hline 食道垔全摘術 & 4 & 1 & 1 \\
\hline 肝切除術 & 2 & 2 & 0 \\
\hline その他 & 9 & 6 & 3 \\
\hline
\end{tabular}

平均土標蕉偏差

群 (PCA-Pe 群) 20例の 3 群について比較検討した，患 者の年址命，体重においては 3 群間に有意差は認められ なかった(表 1)。本臨床研究は，手術前に各患者に臨 床研究の内容を説明し承諾を得たのち行った。

使用器材は, Bu 群ではバクスターインフューザー マルチデイタイプを, PCA-Bu 群と PCA-Pe 群ではバ クスターインフューザーBB60とバクスターイン フューザー用 PCM を用いた（図 1). 


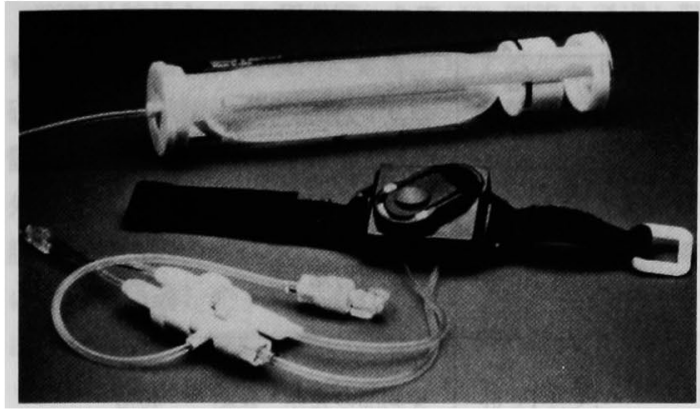

図 1 PCA システム：バクスターインフューザー BB60およびパクスターインフューザー用 PCM.

注入薬液はBu群および PCA-Bu群はブレノル フィン2.0mg +生理食塩水 $50 \mathrm{ml}, \mathrm{PCA}-\mathrm{Pe}$ 皮下群はぺ ンタゾシン $300 \mathrm{mg}+$ 生理食塩水 $50 \mathrm{ml}$ を基本投与とし て，いずれも投与量 $0.5 \mathrm{ml} / \mathrm{h}$ の設定で行った. PCA 群 の追加投与量は $0.5 \mathrm{ml}$, 不応時間 1 時間とした.

疼痛時には Bu 群ではブプレノルフィン $0.2 \mathrm{mg}$ を筋 注, PCA 群では(1)追加投与ボタンを操作 (患者に操作 方法を教え原則として患者自身が，必要あればナース あるいは医師が操作),(2)上記施行してもなお疼痛を訴 える場合には PCA-Bu群ではププレノルフィン 0.2 $\mathrm{mg}$ を, PCA-Pe 群ではペンタソシン $30 \mathrm{mg}$ を筋注し た.

なお今回の研究において,「補助鎮痛薬」とは「疼痛 時に使用した筋注の薬」を指すこととする。

3 群とも手術終了しICU 入室直後に皮下持続注入 を開始し，原則として第 5 病日まで継続し行った。

鎮痛効果の判定は，皮下持続注入を開始してから 3 時間後と，第一病日，第二病日，第三病日，第四病日 の早朝に行った.

鎮痛度として,

0 点：全く痛みを感じない。

1 点：安静臥床で痛みを感じないが, 体動時軽度の 痛みを感じる。

2 点：安静臥床で軽度の痛みを感じる.

3 点：安静臥床で耐えられない程の痛みを感じる。 以上の 4 段階の pain score を設定し，患者血身に質問 して採点した.

なお補助鎮痛薬使用者の割合，追加投与ボタンの使 用者の割合と操作回数(PCA-Bu 群と PCA-Pe 群), フ プレノルフィンの総投与量 (Bu 群と PCA-Bu群で, 基 本投与量と疼痛時の投与量を加算した総量）を検討し た.また全期間を通じての副作用の発現頻度と種類を

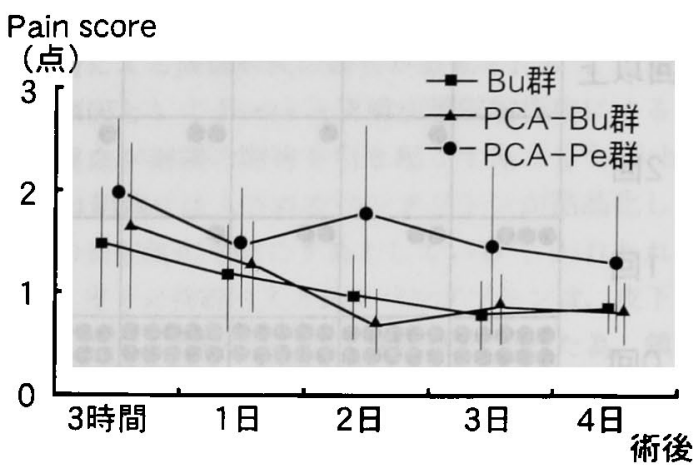

图 2 鎮痛効果の経時的变化

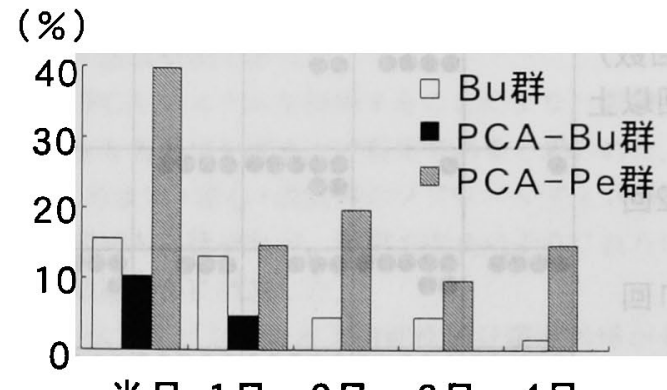

当日 1 日 2日 3 日 4 日

術後

図 3 補助顉痛薬使用者の割合

検討した。

統計学的処理は $\mathrm{t}$ 検定法, $\chi^{2}$ 検定法, 分散分析法にて 行い, $\mathrm{p}<0.05, \alpha<0.10$ を有意とした。

\section{1) 鎮痛効果}

結 果

pain score における 3 群間の比較をした，術後は経 過するに従い 3 群共に pain score は低下した。Bu 群 と PCA-Bu群は全期間を通して有意差は認めなかっ た. Bu 群と PCA-Pe 群は全期間を通して有意差を認 めた.PCA-Bu 群と PCA-Pe 群は第二病日から第四病 日にかけて有意差を認めた（図 2 ）。

2）補助鎮痛薬使用者の割合

ナースコールで笳肉注射を要求し施行された患者の 割合を 3 群間で比較した. PCA.Pe 群は, Bu 群と比較 して全期間を通し有意に多かった。

PCA-Bu 群は, 第二病日以降で補助鎮痛薬を使用し た㭧者はいなかった，Bu群と PCA-Bu群との比較で は，各期間で有意差は認められなかった（図 3)。

3）追加投与ボタンの使用者の割合と操作回数 PCA-Bu 群では $25 \%$, PCA-Pe 群では70\%の患者が 


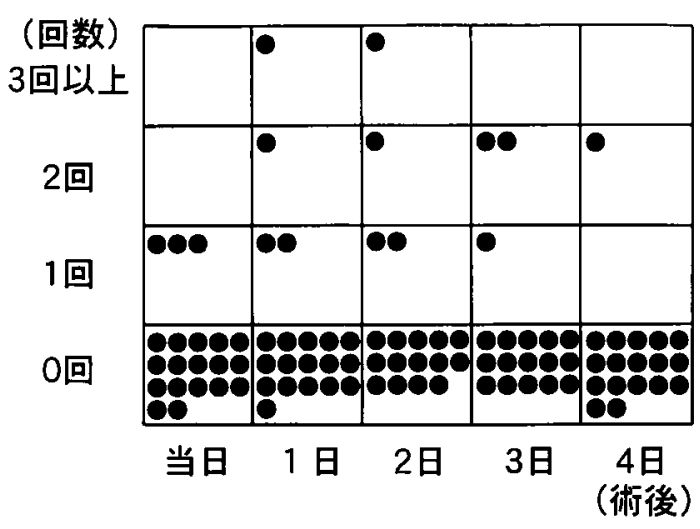

图 4 PCA-Bu 群の追加投与ポタン操作回数

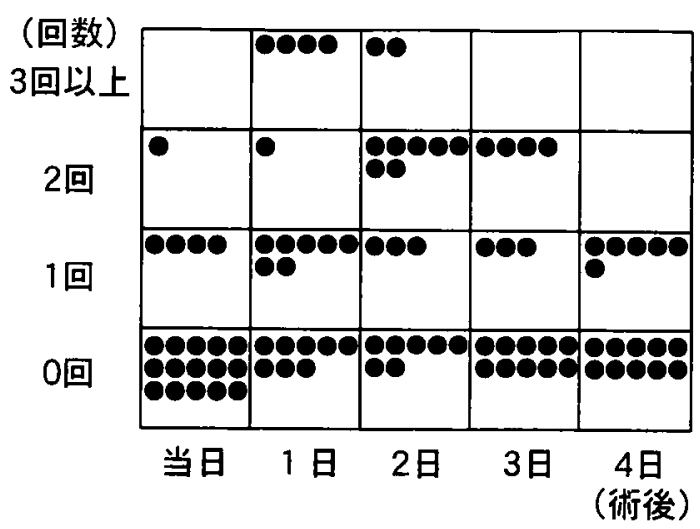

図 5 PCA-Pe 群の追加投与ボタン操作回数

使用した. PCA-Bu群での操作回数は術当日 0 回 17 人 (85\%)，1 回 3 人 (15\%), 第一病日 0 回 16 人 (80\%), 1 回 2 人 ( $10 \%), 2$ 回 1 人 $(5 \%), 3$ 回以上 1 人 ( $5 \%)$ ，第二病日 0 回 14 人 (78\%)，1 回 2 人 (11\%), 2 回 1 人 $(6 \%), 3$ 回以上 1 人 $(6 \%)$, 第三病日 0 回15人 (83\%), 1 回 1 人 ( $6 \%), 2$ 回 2 人 (11\%), 第四病日 0 回 17 人 (94\%)，2回 1 人（6\%）であった (図 4 ).

PCA-Pe 群での操作回数は術当日 0 回 15 人 ( $75 \%)$, 1 回 4 人 (20\%)，2 回 1 人 (5\%), 第一病日 0 回 8 人 $(40 \%), 1$ 回 7 人 $(35 \%), 2$ 回 1 人 $(5 \%), 3$ 回 以上 4 人 $(20 \%)$, 第二病日 0 回 7 人 $(37 \%), 1$ 回 3 人 $(16 \%), 2$ 回 7 人 $(37 \%), 3$ 回以上 2 人 $(11 \%)$, 第三病日 0 回 10 人 (59\%), 1 回 3 人 $(18 \%), 2$ 回 4 人 $(24 \%)$ ，第四病日 0 回 10 人 $(63 \%) ， 1$ 回 6 人 $(38 \%)$ であった（図5）。

追加投与ボタンの平均操作回数は, PCA-Pe群は $\mathrm{PCA}-\mathrm{Bu}$ 群と比較し全期間を通して有意に多かった。
表 2 副作用

\begin{tabular}{c|lr}
\hline \multirow{3}{*}{ Bu 群 } & なし & $85 \%$ \\
& 混乱・幻覚 & $6 \%$ \\
& 罳心・嘔吐 & $5 \%$ \\
& めまい & $4 \%$ \\
\hline \multirow{3}{*}{ PCA-Bu 群 } & なし & $90 \%$ \\
& 混乱・幻覚 & $5 \%$ \\
& めまい & $5 \%$ \\
\hline \multirow{3}{*}{ PCA-Pe 群 } & なし & $50 \%$ \\
& 穿刺部の発赤・硬結 & $45 \%$ \\
& 悪心・湢吐 & $5 \%$ \\
\hline
\end{tabular}

\section{4) フフプレノルフィンの総投与量}

$\mathrm{Bu}$ 群と PCA-Bu 群とで, 一人平均使用したブプレ ノルフィンの総量を比較した。 Bu 群は $2.098 \pm 0.72$

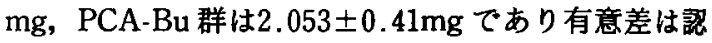
められず PCA-Bu 群の方がむしろ低量であり，本人に 追加投与を任せても過㮃投与になる危険はなかった。

5）副作用

Bu 群には $15 \%$ (めまい $4 \%$, 悪心・嘔吐 $5 \%$, 混乱， 幻覚 $6 \%$ ), PCA-Bu群には10\%（めまい $5 \%$, 混乱・ 幻覚 $5 \%$ ）の副作用が出現したが，いずれも持続注入 を中止することにより速やかに消退した。

PCA-Pe 群には $50 \%$ （悪心・嘔吐 $5 \%$, 穿刺部の発 赤·硬結 $45 \%$ ）の副作用が出現した（表 2 ）。穿刺部の 発赤・硬結は，持続注入中止後も数日間に熱感や痛み が残った。

\section{考 察}

術後疼痛管理は, 患者の苦痛を和らげるだけでなく， 早期離床を促し術後の肺合併症や精神障害の予防にも なると考えられ，術後管理の中でも重要な意味を持つ。 1979年 Behar らによって硬膜外腔へのモルヒネ投与 が, 従来の静脈内, 筋肉内投与に比較してはるかに効 果的で，かつ長時間持続する鎮痛効果をもたらすこと が報告》されて以来，優れた術後疼痛管理法として広 く一般に行われることになった。ささらに鎮痛効果を持 続させ医療の省力化を図るために自動注入器による硬 膜外持続注入法が登場し, 注入器も軽量, 簡易化され た製品が普及した. 一方，モルヒネは抗ヒスタミン作 用，呼吸抑制などの副作用と，麻薬であることによる 使用上の煩雑さがあるため，近年非麻薬性鎮痛片であ るププレノルフィンが頻用されている.ププレノル フィンは強力な鎮痛作用と長い効果持続時間が認めら れ，硬膜外腔投与においてもモルヒネ同様の鎮痛効果 を有する2!。 
硬膜外腔投与の作用機序は主に, 1）硬膜を通過し脳 脊髄液を介して脊䯣後角に直接作用するルートと，2） 硬膜外腔の脂肪組織に吸収され血行性に脳あるいは脊 髄に作用するルートがあると考えられている3．硬膜 外投与においてモルヒネは水溶性のため硬膜外腔の脂 肪や血管への吸収は少なく，かつ分子量が小さいため に硬膜を通過しやすい，それに対しププレノルフィン は脂溶性が高く硬膜外控の脂肪や血管へ吸収されやす く，かつ分子量が大きいために，硬膜を通過してくも 膜下に到達する量はモルヒネに比較して $1 / 10$ 以下と少 ないとされている゙.このことから,ププレノルフィン の硬膜外投与の作用機序は脂肪組織に吸収される血行 性ルートが優位 ${ }^{5)}$ と考えられ，ブプレノルフィンの皮 下投与でも硬膜外投与とほほ同様の鎮痛効果が期待で きると考えられる．松元ら ${ }^{6}$ は術後疼痛管理において ププノルフィンの皮下持続注入法は, 硬膜外持続注 入法と同様に有効であったと報告しており，また今回 われわれの研究結果でもブプレノルフィンの皮下持続 投与で満足のいく鎮痛効果が得られた。ささらに硬膜外 注入法のチューブ挿人時の患者の苦痛, 手技の煩雑さ や危険性を考慮すると, 術後疼痛管理においてブプレ ノルフィン皮下持続注入法は, 硬膜外持続注入法に とって代わる優れた方法と言える.

しかし鎮痛効果は個人差がありププレノルフィン皮 下持続注入法だけでは23.5\%の患者が補助鎮痛薬を要 した. 今回, PCA システムを用いることによる補助鎮 痛楽の使用頻度の隇少に有意差は認めなかった。しか し, PCA システムは, 疼痛が出現し補助鎮痛薬が投与 されるまでの患者が苦しむ time-lag をなくし，かつ薬 液の過剩投与の危険性もない為, 医療の安全な省力化 を図る上で有用であると思われる。

フプレノルフィンを使用した群の副作用として約 10\%にめまい, 悪心, 意識障害の症状が出現し, これ らの症状は注入を中止することによりすぐに軽快し た.この副作用の発現率は決して無視できず今後の課 題である. 疼痛の域值が高いとされる高齢者でかつ術 後精神障害が墦念される症例に対しては, フブレノル フィン皮下持続注入法を最初から使用することは避け るべきと考える.

今回われわれはペンタゾシンの皮下持続注入も行っ たが鎮痛効果は有意に悪く，45\%と高率に穿刺部の発 赤・硬結を認めた。ペンタソシンも強力な非麻薬性鎮 痛剂で, めまい, 悪心等の副作用は比較的少なく取扱 いも簡易なため, 癌性疼痛や術後疼痛をはじめ広く使
用されている。しかし皮庙障害の副作用があり，筋注 の頻用による潰場形成の報告が散見される7．皮庙障 害の原因として Parksら皮南血管収縮作用による局 所の虚血が組織の障害を引き起こす為とし ${ }^{8)}$, Schlicher は組織に注入されたペンタソシンが結晶化して 組織の炎症反応を起こす為としている9．われわれの 場合，皮下に持続注入されたペンタソシンは，皮下に 停滞したまま血中にほとんど移行しなかった為，鎮痛 効果が悪くその上皮间障害を高率に起こしたものと考 えられる.このことからペンタソシンの皮下持続注入 は避けるべきであると思われた。

\section{結 語}

(1) 術後疼痛管理においてププレノルフィン皮下持 続注入法は有効であった。

(2) PCA システムを併用することにより，医療業務 の安全な省力化を図る上で有用であると思われた。

(3) めまい・悪心・混乱等のププレノルフィンの副作 用は約10\%に認めたが，使用の中止によりこれらの副 作用は速やかに消退した.

(4) ペンタソシンの皮下持続注入は鎮痛効果が有意 に劣り, かつ皮庫障害が高率に出現し安全性に問題が あった。

本論文の要旨は第 5 回愛知臨床外科医学会で発表した。 文献

1) Behar M, Mogora F, Olshwang D, et al: Epidural morphine in treatment of pain. Lancet $1: 527-528,1979$

2）松永万鶴子, 壇健二郎, 比嘉和夫他：開腹術後痛に 対するブプレノルフィンの静注と硬膜外腔投与の 比較. 麻醉 33: 995-1002, 1984

3) Cousins MJ, Mather LE: Intrathecal and epidural administration of opioids. Anesthesiology $61: 276-310,1984$

4) Moore RA, Bullingham RES, McQuay $\mathrm{HJ}$, et al: Dural permeability to narcotics: In vitro determination and application to extradural administration. Br J Anesth 54: 1117-1128, 1982

5）西原 功, 赤塚正文, 田中源重他：術後疼痛に対す るププレノルフィン坐薬の術前投与の有用性一硬 膜外ププレノルフィン投与法と比較して一. ペイ ンクリニック $14: 387-391,1993$

6) 松元 茂, 光畑裕正, 秋山博実他：PCA システム を用いた皮下持続注入法による術後疼痛. 管理・麻 醉 43:1709-1713, 1994 
7）緒方茂寛,田辺 稔：ペンタソシンン溳凊の経験。形 成外科 XXIII : $313-315,1980$

8) Parks DL, Perry HO, Muller SA: Cutaneous complications of pentazocine injection. Arch
Dermatol 104 : 231-235, 1971

9) Schlicher JE, Zueheke RL, Lynch PJ : Local change at the site of pentazocin injection. Arch Dermatol 104 : 90-91, 1971

\title{
THE USEFULNESS OF CONTINUOUS SUBCUTANEOUS INFUSION USING THE PATIENT CONTROLLED ANALGESIA SYSTEM IN THE POSTOPERATIVE PAIN CONTROL
}

\author{
Yuichiro TOJIMA, Katsuyoshi KO, Shin KATAYAMA, Yutaka KOKURA \\ and Atsuyuki MAEDA \\ Department of Surgery, Yamashita Hospital
}

In this study the usefulness of the postoperative pain control was comparatively studied in 135 patients undergoing an abdominal surgery at the hospital by dividing into three groups: 1) 90 patients received continuous subcutaneous infusion of buprenorphine; 2) 20 patients received continuous subcutaneous infusion of buprenorphine using the patient controlled analgesia (PCA) system; and 3) 20 patients received continuous subcutanoeous infusion of pentazocine using the PCA system.

As a result, continuous subcutaneous infusion of buprenorphine was effective in the postoperative pain control, and a use of the PCA system might contribute to the safety personal saving in the medical care. However, it poses a further problem that buprenophine can cause adverse effects such as dizziness and nausea in about $10 \%$ of the patients. Continuous subcutaneous infusion or pentazocin was significantly inferior to that of buprenorphine in the analgesic effect and has a problem in the safety. 